\title{
Sex Hormone-Binding Globulin
}

National Cancer Institute

\section{Source}

National Cancer Institute. Sex Hormone-Binding Globulin. NCI Thesaurus. Code C17128.

Sex hormone-binding globulin (402 aa, $44 \mathrm{kDa}$ ) is encoded by the human SHBG gene.

This protein is involved in steroid transport. 